\title{
Xenophobic attacks on foreign shop owners and street vendors in Louis Trichardt Central Business District, Limpopo Province
}

\author{
KA MOTHIBI', CJ ROELOFSE ${ }^{2}$ AND T TSHIVHASE ${ }^{3}$
}

\begin{abstract}
Xenophobic attacks in South Africa in 2008 and 2015 sent shockwaves through the country and the world. In these events, around 70 people were killed while thousands were displaced; and, property and products of street vendors and shop owners were destroyed. This phenomenological research project is confined to Louis Trichardt in Limpopo Province wherefrom a cohort of foreign street vendors and shop owners were interviewed. The lived experiences of being verbally and physically abused as well as of some acquaintances being killed, has clearly left them traumatised and living in fear. The article finds that contributory factors to xenophobic attacks experienced by foreign shop owners and street vendors range from competition over scarce resources, stereotypes and inter-group anxiety. Finally, it offers some recommendations about education for South Africans and measured police action.
\end{abstract}

Keywords: xenophobia, immigrants, street vendors, violence, South Africa

\section{Introduction}

After 1994, South Africa became an eye-catching destination for migration. The fall of Apartheid resulted in a large flood of refugees and immigrants into South Africa, particularly from other African countries. Estimates of the number of illegal immigrants vary from 2-8 million (Hussein, 1996). This figure, 20 years later, looks reasonably accurate with estimates at 6 million (Wilkinson, 2014). As a result, South Africa's freedom has since the dawn of democracy was increasingly perceived as a centre for economic opportunity (International Marketing Council of South Africa, 2004: 1). As immigrants settled into South African communities, the latter were equally incrementally exposed to foreign nationals' lifestyles. According to McDonald \& Golden (2000: 171), this increase in numbers of refugees and other non-citizens created tension among South African citizens, rendering xenophobia a realistic cause for concern within communities. Overt xenophobia among South Africans was revealed in May 2008 when widespread violent attacks were carried out by crowds of South Africans against African immigrants and other local citizens suspected of being foreign nationals too. Globally, xenophobic violence is a serious phenomenon and it has been a persistent problem that afflicted society at all level (Wilkinson, 2014). There is insufficient criminological research whether foreign shop owners and street vendors living in Louis

1 Department of Criminology, University of Limpopo, Private Bag X1106, Sovenga, 0727, South Africa, e-mail: kholofelo.mothibi@ul.ac.za

2 Department of Criminology, University of Limpopo, Private Bag X1106, Sovenga, 0727, South Africa, e-mail: cornelis.roelofse@ul.ac.za

3 Department of Criminology, University of Limpopo, Private Bag X1106, Sovenga, 0727, South Africa, e-mail: thompho.tshivhase@ul.ac.za

Td The Journal for Transdisciplinary Research in Southern Africa, 11(4), December 2015, Special edition,

pp. 151-162. 
Trichardt community experienced and/or experience xenophobia and the form it takes. The consequences of xenophobia are far-reaching because it impacts significantly on long term and psychological wellbeing of victims. The article aims to identify the contributing factors to and types of xenophobic attacks as well as impact on foreign shop owners and street vendors.

This article is drawn from material that was compiled through qualitative research, which allowed for in-depth and rich understanding of xenophobia from the perspective of the respondents and their social context. Thus, the design is consistent with social constructionism. Convenient sampling design was used, with great care of applicable ethics, to select a total of eighteen (18) participants from Louis Trichardt Central Business District, distributed as follows: ten (10) street vendors and eight (8) business owners, which included five (5) Somalians, four (4) Ethiopians, three (3) Nigerians and six (6) Zimbabweans. All participants were interviewed using face-to-face unstructured schedule either at their home, work and outdoors of their convenience. Based on the prearranged agreement, recordings of the interviews were captured through handwritten notes and on tape. To ensure reliability and credibility the saturation method was employed. The relevance of Louis Trichardt for the study of xenophobia is borne out of its location along the national road N1, just $112 \mathrm{~km}$ from Beitbridge Border Post. Louis Trichardt is a picturesque town at the foot of the Soutpansberg Mountain Range in Limpopo Province, South Africa, often described as the Centre of Makhado Local Municipality. According to the 2011 census, Louis Trichardt's population was made up of 25360 individuals and 7129 households. To establish the bigger picture from the body of data collected, thematic data analysis was applied. In the final analysis, the interview results were interpreted, generalised and summarised in order to make deductions, as reported in this article.

\section{Theorisation of xenophobia in scapegoating theory}

Xenophobia as a social phenomenon that is amenable to a variety of theoretical framings, inclusive of social learning and scapegoating theory. This article seeks to apply the scapegoating theory of xenophobia.

One of the earliest psychological theories explains prejudice and discrimination as a means by which people express hostility arising from frustration. According to Marger (1991: 94), this has also been referred to as scapegoating. In essence, this theory implies that a person becomes so frustrated in his or her efforts to achieve a desired goal that he or she tends to respond with aggression. The source of frustration is unknown or too powerful to confront, so a substitute is found to release the aggression. Marger (1991: 94) notes that the scapegoating theory may at first seem convincing because of the "commonness of experience" because all individuals at some time or the other, experience frustration when needs and desires are not met. For example, if one does not get a promotion there will be feelings of frustration and anger. Whereas displacing anger and frustration on a substitute does not solve the problem, it provides for a temporary relief to an individual's anxiety.

Harris (2001: 5) is of the opinion that the relatively new phenomenon of xenophobia in South Africa is explicable through the scapegoating hypothesis. This theory holds that foreigners are blamed for limited resources such as jobs and education, as well as for "dashed expectations regarding the transitional process". The underlying factor, which is poverty and violence, is directed towards foreigners on the pretext that they commit crimes and take away jobs meant for South Africans. The Centre for the Study of Violence and Reconciliation in 
South Africa notes that discrimination against foreigners takes place in many societies, particularly in countries experiencing political or economic upheaval. It therefore becomes a convenient scapegoating for those experiencing the reality of hardship that has worsened since the arrival of Zimbabweans into South Africa. Targeting foreigners is a matter of proximity because foreigners tend to reside in areas that are characterised by poverty and inadequate service delivery. These conditions are a precursor to xenophobic attitudes that encourage hostility, conflict and violence, as more people are competing for meagre resources (Alarape, 2008: 75).

\section{Defining xenophobia}

Xenophobia is commonly defined as the hatred and prejudice against "outsiders" or foreigners (Harris, 2002). Further, it is also described as fear or contempt of that which is foreign or unknown, especially of strangers or foreign people. Additionally, xenophobia involves the intense dislike, hatred or fear of others perceived to be strangers (Nyamnjoh, 2006: 5). The word xenophobia is derived from two Greek words, that is, xenos meaning stranger and phobia meaning fear. For the purpose of this article, the notions of xenophobia denoted above are held, and the victims of the attendant acts are exclusively the African immigrants in South Africa.

\section{Xenophobic attacks in South Africa}

According to the Southern African Migration Project, South Africa displays one of the highest levels of xenophobia in the world (Crush, 2001). In South Africa, xenophobia appears to be racialised as Black immigrants are the primary targets and victims (Zegeye, 2009: 8), accompanied by demeaning nomenclature, name-calling and verbal abuse. A common insulting term used for foreigners by black South Africans is "makwerekwere" (Zegeye, 2009: 8). This word is meant as an insult and usually applied in the same line with being told to go back home. Many foreigners receive constant harassment and insults from various South African nationals, like shoppers, pedestrians, passengers, neighbours and even work colleagues. Harris (2001: 60) states that to most foreigners, it is a daily practice to be subject to public hostility.

Also, xenophobia displays itself through acts of looting and destruction of property of vulnerable groups of foreigners. In March 2014 a number of Somalis and Chinese allegedly fled the Moletlane Village in Limpopo Province, where they had been residing and earning a living, after their shops were looted and set alight by residents. Police spokesperson, Ronel Otto said "43 men and 20 women were caught on Sunday after five Chinese-owned shops were touched out of resentment toward foreigners but also could specifically target foreign nationals on the basis of their vulnerability - for example, due to the perception that state authorities such as South African Police Services will not protect them. Given that xenophobic violence deliberately targets people on the basis of their actual or perceived "foreignness", it can also be seen as a form of discrimination. Nkosi (2015: 1) writes that the South African Police Service's Operation Fiela (meaning reclaim) is in fact xenophobic in itself. But despite the apparent success of the anti-crime operation, a coalition of nongovernmental organisations, including Lawyers for Human Rights, Médecins Sans Frontières, Section 27, Corruption Watch, Africa Diaspora Forum and Awethu, has criticised Operation Fiela for perpetuating xenophobia. They say the campaign is unfairly targeting foreign nationals and mistakenly equates the presence of undocumented foreigners in South Africa with crime. 
Xenophobic violence is one common form of bias motivated violence (also known as "hate crime") that can be difficult to distinguish from, and sometimes overlaps with, other forms. For example, some cases of xenophobic violence may also be related to other forms of prejudice such as racism, religious intolerance or persecution on the basis of sexual orientation or gender identity. According to Nkosi (2015: 1), xenophobic violence, like other forms of bias-motivated violence, can often serve as a "message crime", in that an act of violence can be intended to send a signal to other refugees or migrants that they are not welcome in an area or country. Some perpetrators of violence may believe that they have the support of political leaders in their actions and this perception is affirmed if government leaders fail to speak out after major incidents of xenophobic violence or the police do not act decisively and arrest perpetrators. Likewise, perpetrators of xenophobic violence may feel vindicated if their actions pressure government to conduct increased immigration raids or deport undocumented victims of the violence.

According to Nkosi (2015: 10), xenophobic violence can take on different forms in different regions of the world. In some states, individual attacks on foreign nationals by extremist groups may be the norm. In South Africa, xenophobic violence may be perpetrated by mobs that go door to door within their own neighbourhood in search of foreign nationals. New24 (2012) argues that the xenophobic violence may also have an economic dimension in cases where foreign-owned businesses are specifically targeted for looting and robbery. There is also a gender dimension to xenophobic violence wherein foreign nationals are targeted for sexual and gender-based violence. It is evident that foreign shop owners and street vendors have endured xenophobic attacks; and, it is equally important to examine the nature of these attacks against foreign shop owners and street vendors, as presented hereunder.

Since South Africa gained independence from the Apartheid regime in 1994, numerous xenophobia-related attacks have been reported in media resulting in deaths, injuries and displacement (Crush, 2008: 47). For instance, Human Rights Watch (2008: 128) found that there was serious tension between South Africans and foreign street traders or hawkers, which resulted in acts of violence and intimidation. Apparently, South Africans did not want to share pavements with foreign hawkers, to the extent that they embarked protest marches. On several occasions they had viciously attacked foreign hawkers with instruments like "knobkerries" (sticks with a rounded ball at the end) and "sjamboks" (flexible rubber stick). As a result, many foreign traders gave up hawking in fear of their lives. When one look at reasons for these attacks, Anyadike (2015: 1) quotes Steytler form the Institute of Race Relations thus:

"We don't believe that the xenophobic violence is about foreign nationals 'stealing jobs'. It's about deep economic inequality and the government's failure to implement policies that create jobs and grow the South African economy. It's about dire socio-economic circumstances for the majority of South Africans"

This observation is borne out by an incidents that happened in January 2002, in the Joe Slovo settlement in Milnerton, near Cape Town, where three refugees and, a day later, one local man were killed. The three refugees that were killed were then dragged into a house, which was subsequently set alight. These apparent xenophobic killings occurred because Xhosaspeaking residents complained that foreigners who were also street vendors were having relationships with "their women" and stealing their jobs (Anyadike, 2015: 2).

The South African Red Cross Society (SARCS) has also reported that over 500 foreign nationals have been displaced in xenophobic attacks in Botshabelo in the Free State (News24, 
2012). A plethora of other violent acts against immigrants and refugees, such as being thrown off moving trains and physical assault, have been reported in the media (Naicker \& Nair, 2000: 2). Evidently, xenophobia in South Africa has had life-threatening consequences for many refugees and foreign nationals, who have ironically immigrated to South Africa in search of work, safety and security.

\section{The impact of xenophobic attacks}

The impacts of xenophobic attacks are diverse and complex, ranging from the physical to the emotional. Hereunder, the article narrates the impacts that are on record.

\section{Death as a result of xenophobic acts}

Neocosmos (2010: 120) argues that many people have been killed as a result of xenophobic violence. He further writes that,

\section{"In May 2008, the country exploded into an orgy of killing, looting and burning. The outcome in Gauteng was 62 people dead of whom 21 were South Africans."}

In 2001, violent clashes broke out in Milnerton between Angolans and South Africans wherein locals accused immigrants of taking their jobs and women. Three Angolans and one South African accused of killing one of the immigrants were in turn killed. In 2004, a Somali shop owner was shot dead in broad daylight in his own shop on Christmas day. Nothing was stolen; as a result, xenophobia was thought to be the motive. In 2005, three Somali refugees were stabbed to death outside their shop. The attacks were thought to be motivated by xenophobia and resentment of their successful businesses. In 2006, violent riots erupted in Choba between foreigners and local residents, wherein the latter claimed that foreign nationals steal their jobs. Two migrants were killed, including a Zimbabwean man who was burnt to death. Additionally, two Zimbabweans were killed in violent clashes between South Africans and foreigners in the informal settlement of Olievenhoutbosch in 2006. Again in 2006, at least one man was killed when violence erupted against foreigners in Plettenburg Bay; and, the reason was that they were stealing jobs from the local residents.

In 2007, two Somali men were burnt alive in their shop in Mossel Bay, the night after another Somali man was killed by armed gangs in Cape Town. In January 2008, four foreign nationals broke into a spaza shop (small backyard grocery shop) owned by a local trader in Soshanguwe and they were apprehended by local residents burnt one of them to death. Following this incident, local residents called on all foreigners to leave. In March 2008, at least seven lives were lost in a series of attacks spanning a week in Atteridgeville. The deceased included Zimbabwean, Pakistani and Somali nationals as well as a South African who was mistaken for an immigrant. Over the period between March and June 2008, several deaths of foreigners and South Africans mistaken for immigrants and killed, were recorded. The causes of death include beating, stoning, burning, shooting and neck-lacing. There were more than 60 confirmed deaths the attacks subsided. The incidences outline above highlight the violent nature and extent of xenophobic violence in South Africa. The incidences show that the violence was on the rise. The reasons for the rise in xenophobic attacks, which may include laxity of the criminal justice system in dealing with xenophobic violence in South Africa, are yet to be fully understood. 


\section{Physical effects of xenophobia}

Higson \& Suffla in O’Neill (2011: 374) note that,

"violence is understood as an act or situation that harms the health or well-being of oneself or others. It includes both attacks on a person's physical and psychological integrity, and the destructive acts that do not involve a direct relationship between victims and the institution, person or persons responsible for the harm."

Clearly, the effects of violence include physical harm to people and physical destruction of property. McConnell (2008) states that, "Foreign owned businesses were destroyed amounting to over R1.5 billion in damages." McConnell goes further to note that, although these foreign-national owned businesses contribute up to almost $25 \%$ of the gross domestic product (GDP) in South Africa, government did not compensate for the losses nor offer assistance to businesses that were destroyed during the attacks.

Xenophobic attacks that occurred on the $11^{\text {th }}$ until the $28^{\text {th }}$ May 2008, left 37500 foreign nationals displaced around the country. The attackers did not give anyone a chance to collect any valuables, instead they made sure that foreign nationals ran for their lives, leaving behind their hard-earned possessions for the looters. McConnell (2008) argues that the media is also awash with headlines of the destruction of foreign-owned businesses and incidents of grievous bodily harm of immigrants. Indeed, xenophobic attacks have far reaching physical effects that could permanently impair the victims' ability to practice viable livelihood.

\section{Psychological effects of xenophobia}

O'Neill (2011: 377) finds that victims of horrific experiences where an individual literally faces death and extreme forms of violence such as xenophobic attacks, can develop traumatic stress disorder which results from moments of overwhelming fear, horror or helplessness. He further explains that such experiences are deeply distressing and potentially life-changing. According to O'Neill (2011: 377), “Traumatic stress is a phenomenon of the psychological world which is less observable and can only be understood through close examination of the behavioural changes in people who have recently survived a violent incident or through the survivors' descriptions of their feelings and thoughts." Traumatic stress, as seen by O'Neill (2011: 378), can lead to the following symptoms:

- Re-experiencing symptoms which are associated with thoughts, feelings, psychological responses and behaviours which remain with the person long after the traumatic event is over; and, they may take forms of memories, intrusive images or flashbacks. This will mean that, even though the incident is in the past, the mind and body may still react to triggers associated with the past traumatic event.

- Avoidance symptoms, which are strategies people use to try to avoid the fear and pain caused by their on-going re-experiencing of the event. Very often, people stay away from people, places and activities that remind them of the nasty experience.

- Arousal symptoms are closely related to people's highly developed survival mechanisms whereby following a traumatic experience, people often find it very difficult to fall asleep and are easily woken up, often hyper vigilant and quick to anger.

Traumatising experiences can cast a long shadow over people's lives, including perpetrators as well as victims. That is, the effects of the experience can be radical and long lasting. 


\section{Findings and discussions}

The sample was made up of seven (7) female street vendors and eleven(11) males. Eight (8) of the males were shop owners and (3) were street vendors. Whereas a non-probability sampling design was used, it can be assumed that immigration into South Africa has involved both males and females; and, they included Zimbabwean, Somalian, Ethiopian and Nigerian nationals. All participants stayed in South Africa for less than fifteen (15) years-

\section{Xenophobic attacks on foreign shop owners and street vendors in Louis Trichardt}

Causes of xenophobic attacks as seen by foreign shop owners and street vendors

There were numerous themes observed from the responses of the participants, including the causes and impacts of xenophobia. Most participants as foreign shop owners and street vendors believed that they were perceived as endangering the existence of individuals, socially, politically, economically and even physically. Indeed, Alarape (2008:75) maintains that the prevalence of xenophobia in a society is not necessarily linked to levels of unemployment. Rather, the key to understanding xenophobia may be the perception of how legitimate the competition is as well as the perception about equality and difference.

\section{Media}

Danso \& McDonald (2000: 1) see media as a powerful vehicle for social transformation and development. When it comes to the issue of xenophobia and the media in South Africa, respondents felt that the media vilifies them; and, one participant notes:

"I strongly believe that the media also play a role in encouraging people to attack us because some stories in radios they always preach the dirty gospel about us"

\section{Stealing women}

One of the issues cited by some authors as a reason for xenophobic violence in South Africa is in the locals' thinking that foreigners "steal" their women (Mnyaka, 2003: 21). Male participant in this study also stipulated they are often attacked or threatened over the relationships they have with local women. Two male participants responded, thus:

"When they see you they only associate you with bad things like maybe you want to sell drugs, or you want to take their women, you want to take their jobs".

"For me it was very painful because I was threated most of the time, they said I was exploiting their sisters and as results I had to break up with my girlfriend because of that."

\section{Intergroup anxiety}

Stephan \& Stephan (2000) suggest that individuals in the in-group experience feelings of threat when interacting with members of the out-group in ways that challenge their selfimage (for example, being embarrassed when in contact with something unfamiliar), and this threat perception causes anxiety. The majority of the respondents believed that the attacks they have experienced were related to inter-group anxiety. Two respondents mentioned that: 
"I was victimised before and from what I've seen since I came here they think you are a thief just because of your foreignness and I realised that the people just seem to hate us over nothing but just because I'm a foreigner"

"When they see you they only associate you with bad things like maybe you want to sell drugs, or you want to take their women, you want to take their jobs".

Competition over scarce resources

McConnell (2008) states that, "Foreign owned businesses were destroyed amounting to over R1.5 billion in damages." The majority of the participants believed that South Africans perceived them as a threat and competition over the natural, economic and social resources. These sentiments were raised by participants as follows:

"I think is because some people around here they are just selfish and they don't have a spirit of Ubuntu, so when they see us they see competition and stranded people”.

"I was once arguing with a friend of mine and I asked them do you hate us so much, so they said we are taking their wives and their space of living and that we are also taking their jobs".

Most participants thought that most South African street vendors and business have negative attitudes towards them, which they blamed on "jealous", as described by three respondents:

"Since I arrived in Louis Trichardt negative attitude towards me has been a normal part of my life, more especially from my fellow business compotators they always say bad things about foreigners but there's notbing I can do about life goes on"

"I think these negative things they always say about foreigners it's the strategy it's a strategy to keep the customers away from our business."

"I was victimised before and from what I've seen since I came here they think you are a thief just because of your foreignness"

Forms of xenophobic attacks

\section{Physical brutality}

Most (85\%) respondents mentioned having experienced some form of physical brutality at the hands of local residents and government officials. One respondent described the violence thus:

"with all experiences since I came here, I've learned that people around here are brutal and violent, I was once being chased out here were I am selling because I was suspected of being a pickpocketing people passing by just because am a foreigner and a man on that case."

\section{Markets demolition}

Harris (2001: 60) states that to most foreigners, it is a daily practice to be subjected to public hostility. Xenophobia also displays itself through actions like looting and destruction of property of vulnerable groups of foreigners. The majority of respondents had experienced market demolition. Two respondents note that: 
"Early this year in March we had flee here in the town, after our shops and markets were looted and set alight by the local residents"

"The last time when people where striking for service delivery around here they never gave us a warning or a short notice for not selling on the day and all my stuff were destroyed and the fruits I was selling was scatted around the streets I was left without a stock"

\section{Verbal attacks}

Participants have overwhelmingly recorded verbal attacks as their daily experience. Harris (2001: 60). A common insulting term used against foreigners is "makwerekwere".

"For me working here every day is distressing because I receive constant harassment and insults from various South Africans, like shoppers, pedestrians, passengers, neighbours and even work colleagues who are also selling around."

\section{Discrimination}

Discrimination was one of the popular themes that kept emerging from the participant's individual expression. Local people were described by most foreigners as not accommodative and suffering from, as phrased by one respondents, "Alien-Phobia". Two participants note as follows:

"The first week I personally discovered that I was not appreciated or welcomed and there was this feeling of being separated from the general local population"

"More especially here at the taxi rank I felt so isolated feeling like an island because people will even go to an extent where they didn't want to buy from me because am not one of them".

\section{Effects of xenophobic attacks}

Death

The majority of respondents believe that killing of foreigners takes place as a results of xenophobic violence. Neocosmos (2010: 120) states that 83 people were killed in this way, inclusive of 21 South Africans, in May 2008.

"last year my colleague was attacked by few people selling around here in town I was also insulted because am selling the products that they are selling with lower prices than theirs, I was also told to go sell my stuff back In Somalia and unfortunately he was brutally injured and he later passed on I hospital".

"early this year I witnessed one of my fellow country man while he was being brutally beaten to death at the taxi rank where I was selling my stuff before I moved to this side, he just was suspected of selling drugs to school kids who pass by going to this high school in town just because he is Nigerian".

\section{Physical effects}

The majority of participants reported that they have been victims of physical attacks, which has become normal and accepted among. Crush (2008:55) notes this point of widespread 
xenophobic consciousness that has normalised in South Africa. The following quotes reiterates incidents of physical abuse:

"At first I thought this thing of xenophobia around here was just a myth and it doesn't exist, but to my surprise I realised that am being physical abused day in day out simply because of my foreignness around here, and even the government officials they also call by offensive names around here and push us".

"I think these physical brutal things they always do to us as foreigners it's the strategy it's a strategy to keep the customers away from our business".

Psychological impact

Respondents' sentiments revealed the extent of fear associated with xenophobic attacks, thus:

"Personally and honestly speaking every day is a challenge to me, even when I'm selling around here I don't feel free to do my business as I am scared".

"To me here living in fear it's now a normal thing as I go through it every day, I have been suspected as a thief numerous times so where ever I am m always alert and scared".

"I'm always not free in my own shop and I am even scared of my own customers its hard running business here as a foreigner".

Loss of income

One of the aspects mentioned by most of the participants was that of loss of income. They believe that xenophobia is costly as they lose income and jobs, as evidenced in the following responses:

"The year I was attacked I spent weeks surviving by asking money for food from my pastor, this was because my spaza shop here was demolished and I had nowhere to get money".

"They just demolish our markets and chase us out of this streets knowing that we won't be able to make money anymore".

Three proposals were drawn from the investigation in regard to addressing xenophobia and the attacks; and, they included awareness campaign, police visibility and harsh punishment.

\section{Conclusion}

The article has argued that contributory factors to xenophobic attacks experienced by foreign shop owners and street vendors ranges from competition over scarce resources, stereotypes and inter-group anxiety. The impact of xenophobic attacks on foreign shop owners include death, injuries, loss of income, destruction of property and products, and looting of businesses. The article suggests that possible measures for addressing xenophobic and the attacks faced by foreign shop owners and street vendors should include public education, police visibility and strengthening of the criminal justice system.

\section{References}

Alarape, A.I. 2008. Xenophobia: contemporary issues in psychology. IFE Psychology: An International Journal, 16(2): 72-84. 
Anyadike, O. 2015. South Africa's Xenophobia Problem: Dispelling the Myths. http://www.irinnews.org/report/101384/south-africa-s-xenophobia-problemdispelling-the-myths [Accessed: 31 July 2015].

Bless, C., Smith, C. \& Kagee, A. 2006. Fundamentals of social research methods an African perspective, ( $4^{\text {th }}$ edn.). Cape Town: Juta \& Co- Ltd.

Braun, V. \& Clarke, V. 2006. Using thematic analysis in psychology. Qualitative Research in Psychology, 3: 77-101.

Burns, N. \& Grove, S.K. 2001. Understanding Research. Philadelphia: W.B. Saunders Company.

Crush, J. (ed.). 2001. Immigration, xenophobia and human rights in South Africa. Migration Policy Series, No. 22. Cape Town and Kingston: Idasa and Queen's University.

Crush, J. 2008. South Africa: Policy in the Face of Xenophobia. SA Migration Project. http://www.migrationpolicy.org/article/south-africa-policy-face-xenophobia [Accessed: 23 May 2014].

Danso, R. \& McDonald, D.A. 2000. Writing Xenophobia: Immigration and the Press in PostApartheid South Africa. Cape Town: SAMP.

Harris, B. 2001. A Foreign Experience: Violence, Crime and Xenophobia during South Africa's transition, in Violence and Transition Series. http://www.wits.ac.za/csvr/pubslist/pubsxen.htm [Accessed: 16 May 2014].

Harris, B. 2002. Xenophobia: A new pathology for a new South Africa? In Psychopathology and Social Prejudice. Cape Town: University of Cape Town Press. http://www.wits.ac.za/csvr/pubslist/pubsxen.htm [Accessed: 16 May 2014].

Human Rights First, 2011. American Ideal and Universal Value, Annual Report. http://www.humanrightsfirst.org/annualreport/2011 [Accessed: 17 May 2014].

Human Rights Watch, 2008. Neighbours in Need: Zimbabweans Seeking Refuge in South Africa. http://www.human.rights watch.com [Accessed: 20 May 2014].

Human Rights Watch, 2009. No Healing Here. http://www.human.rights watch.com [Accessed: 20 June 2014].

Hussein, S. 1996. Strategic Perspectives on Illegal Immigration into South Africa. https://www.issafrica.org/pubs/ASR/5No4/StrategigPerspectives.html [Accessed: 27 July 2015].

International Marketing Council of South Africa, 2004. http://www.gcis.gov.za/content/newsroom/speeches/pcomm/gcis-budget-vote-2004international-marketing-council [Accessed: 21 April 2014].

Marger, M.N. 1991. Race and Ethnic Relations: American and Global Perspectives, (2 ${ }^{\text {nd }}$ edn.). Belmont: Wadsworth.

McConnell, C. 2008. Migration and xenophobia in South Africa. Conflict Trends, 1: 34-40.

Mnyaka, M.N. 2003. Xenophobia as a Response to Foreigners in Post-Apartheid South Africa and Post-exibilic Israel: A Comparative Critique in the Light of the Gospel and Ubuntu Ethical Principles. Pretoria: Unisa. 
Naicker, P. \& Nair, R. 2000. To be a Refugee in South Africa. http://www.queensu.ca/samp/migdocs/Documents/2000/3.htm [Accessed: 23 April 2014].

Neocosmos, M. 2010. From "Foreign Natives" to "Native Foreigners": Explaining Xenophobia in Post-Apartheid South Africa Citizenship and nationalism, Identity Politics. Dakar: CODESRIA.

News24, 2012. Foreigners Evicted from State Shops. http://www.news24.com/SouthAfrica/News/Foreigners-evicted-from-Free-Stateshops-20120711 [Accessed: 31 July 2015].

Nkosi, O. 2015. Xenophobia: They Know they can Kill us and we can't do a Thing. http://mg.co.za/article/2015-05-21-xenophobia-they-know-they-can-kill-us-and-wecant-do-a-thing [Accessed: 15 May 2015].

Nyamnjoh, F.B. 2006. Insiders and Outsiders: Citizenship and Xenophobia in Contemporary Southern Africa. Dakar: CODESRIA.

O’Neil, V. 2011. Psychology: An introduction, (3 ${ }^{\text {rd }}$ edn.), Cape Town: Oxford University Press Southern Africa.

Stephan, W.G. \& Stephan, C.W. 2000. An Integrated Threat Theory of Prejudice. Hillsdale, NJ: Lawrence Erlbaum.

Wilkinson, K. 2014. Are there 70-million People in South Africa? http://mg.co.za/article/201412-04-are-there-70-million-people-in-south-africa [Accessed: 5 July 2014].

Zegeye, A. 2009. Thinking of "Makwerekwere": Racism in South Africa. http://www.apartheidarchive.org/content/abstracts/abstract_zegeye.pdf [Accessed: 30 July 2015]. 